Endocrinol. Japon. 1959, 6 (3), 149 152

\title{
TRF CONGENTRATIONS IN VARIOUS TISSUES FOLLOWING ANTERIOR HYPOTHALAMIC LESIONS
}

\author{
KISHUO SHIBUSAWA, TAKANOBU YAMAMOTO, KAHEI NISHI, \\ CHIAKI ABE, SATOSHI TOMIE AND KAZUO SHIRO'TA
}

\author{
Department of Surgery, School of Medicine, \\ Gunma University, Maebashi
}

TRF (Thyrotrophin-Releasing-Factor) is produced in the anterior hypothalamus, deposited in the neurohypophysis, and then passed into the cerebrospinal fluid and the blood stream to be excreted into urine (Shibusawa et al., 1959c). It has been demonstrated neither in the median and posterior hypothalamus, nor in other tissues, and body fluids. It is an hitherto unknown hormone which controls the thyroid function by acting upon the adenohypophysis via the hypophyseal portal vein or systemic circulation (Shibusawa et al., 1959c). The concentration of this "hormone" in the anterior hypothalamus and the neurohypophysis varies chiefly depending on the balance between the production and release of TRF. The activity of the anterior hypothalamus, therefore, should not be discussed by the assay of the concentration of the hormone in these areas alone. In this experiment, the distribution of TRF was investigated in various tissues of dogs after giving electrolytic lesions to the anterior hypothalamus bilaterally, which is regarded as the site of the production of TRF.

\section{METHODS}

1. As experimental animals, male mongrel dogs (weighing $10 \sim 13 \mathrm{~kg}$ ) were used.

2. Electrolytic lesion was given bilaterally to the anterior hypothalamus using a stereotaxic instrument designed by the Brain Research Institute of Tokyo University. According to the method used by Harris (1950) and Nishi (1959), the electrodes were introduced into the brain, a current of $2 \mathrm{~mA}$ being passed for 5 secs. The site of the lesion was examined histologically.

3. Preparation of TRF. Crude extract was prepared according to Shibusawa et al. (1959a). The separation of TRF from this crude extract by column chromatography will be described elsewhere.

4. Unit of TRF. The amount of TSH released into systemic circulation by the administration of TRF was determined according to Crooke \& Mathews (1953) and expressed in term of J.S.U.

\section{RESULTS}

When the effects of stressors disappear one week after the lesion, crude TRF

Received for publication May 29, 1959. 
was extracted from the anterior hypothalamus, neurohypophysis, cerebrospinal fluid, blood and urine to determine the concentration in these organs. The determination was repeated at the end of 4 postoperative weeks. The results are shown in Table 1. The sites of lesion were found in the rostral and median parts of the median eminence near the base, extending between the supraoptic nuclei and the anterior hypothalamic areas and the paraventricular nuclei. After the experiment, the site of lesion was examined histologically, and such cases where the site was inaccurate or the lesion extended to the other hypothalamic nuclei or areas were omitted. As shown in Table 1, TRF disappeared completely at the end of one week after the lesions. After 4 weeks, however, TRF was found again in the neuro-hypophysis, blood, spinal fluid and urine in all the dogs, suggesting the compensatory mechanism of the remaining tissue of the hypothalamic center, but its concentration was about $1 / 10$ of the control. Lesions in the anterior hypothalamus thus caused a striking decrease in the concentration and a definite change in the distribution of TRF in the body, resulting in an almost complete disappearance; the restoration being extremely slow.

Table 1. Effects of lesions in the anterior hypothalamus on the distribution of TRF (Dogs)

\begin{tabular}{|c|c|c|c|c|c|c|}
\hline \multirow[b]{2}{*}{ Ant. hypothal. } & \multicolumn{2}{|c|}{$\begin{array}{c}\text { Control } \\
\text { TSH (J.S.U.) }\end{array}$} & \multicolumn{2}{|c|}{$\begin{array}{c}1 \text { week } \\
\text { TSH (J.S.U.) }\end{array}$} & \multicolumn{2}{|c|}{$\begin{array}{c}4 \text { weeks } \\
\text { TSH (J.S.U.) }\end{array}$} \\
\hline & No. 1 & 0.6 & No. 4 & 0 & No. 7 & 0.22 \\
\hline Neurohypoph. & & 0.98 & & 0 & & 0.14 \\
\hline Cer.-spin. fी. & & 0.185 & & 0 & & 0.023 \\
\hline Serum & & 0.33 & & 0 & & 0.027 \\
\hline Urine & & 0.026 & & 0 & & 0.0026 \\
\hline Ant. hypothal. & No. 2 & 0.65 & No. 5 & 0.045 & No. 8 & 0.23 \\
\hline Neurohypoph. & & 1.02 & & 0 & & 0.185 \\
\hline Cer.-spin. f. & & 0.215 & & 0.004 & & 0.021 \\
\hline Serum & & 0.35 & & 0 & & 0.031 \\
\hline Urine & & 0.029 & & 0 & & 0.0031 \\
\hline Ant. hypothal. & No. 3 & 0.70 & No. 6 & 0 & No. 9 & 0.185 \\
\hline Neurohypoph. & & 1.06 & & 0 & & 0.17 \\
\hline Cer.-spin. fl. & & 0.245 & & 0 & & 0.025 \\
\hline Serum & & 0.37 & & 0 & & 0.031 \\
\hline Urine & & 0.023 & & 0 & & 0.0027 \\
\hline
\end{tabular}

Weight of dog, 10 13 kg; tissue concentration, per each $1 \mathrm{~g}$; blood, spinal fluid and urine concentration, per each $100 \mathrm{cc}$.

\section{DISCUSSION}

The anterior hypothalamus has been considered the site of controlling center of the pituitary-thyroid axis. Effects of the section of the hypophyseal stalk and the electric stimulation of the hypothalamus upon the thyroid have been reported 
(Harris, 1948). Cahane and Cahane (1938), producing lesions in various parts of the infundibular area, reported that the lesion between the optic chiasma and stalk causes the inhibition of TSH secretion. Greer (1952), Bogdanove and Halmi (1953) demonstrated that when injury was placed between the ventromedian hypothalamic and the suprachiasmatic nuclei, no goiter was induced with thiouracil, although $\mathrm{T} / \mathrm{S} \mathrm{I}^{131}$ concentration ratio increased similarly to the normal animal. From this finding they inferred that there should be two factors of TSH, metabolic and growth, only the growth factor being subjected to the hypothalamic control.

As reported previously, TRF is produced in the anterior hypothalamus and excreted in the urine (Shibusawa et al., 1956a, 1959a). In the hypophysectomized animals injected with $\mathrm{TRF}$ the $\mathrm{T} / \mathrm{S} \mathrm{I}^{131}$ ratio and the thyroid weight exhibited different responses which lead to the conclusion that the hypothalamic factor TRF possessed in itself both metabolic and growth activities. The urinary excretion and distribution in the body of TRF, under various functional states of the thyroid were reported previously, suggesting a feed-back mechanism in which the rate of TSH secretion is controlled by the plasma level of circulating thyroidal hormones (Shibusawa et al., 1959b,c). TRF, which has been found in the anterior hypothalamus and urine, may also be demonstrated in the neurohypophysis, cerebrospinal fluid and blood. When a lesion was placed in the anterior hypothalamus in the dog, TRF completely disappeared from the neurohypophysis and blood as well as from the anterior hypothalamus, and its restoration was extremely slow and reached to only about $1 / 10$ of the normal concentration at the end of 4 weeks after injury. From these facts, it seems almost certain that TRF is produced in the anterior hypothalamus.

\section{SUMMARY}

1. When electrolytic lesions were produced in bilateral anterior-hypothalamus in the dog, TRF almost disappeared from the body and could not be detected in the neurohypophysis, cerebrospinal fluid and blood as well as in the anterior hypothalamus. Nor was it excreted in urine.

2. These results are in accordance with the previous report that TRF was present only in the extract of the anterior hypothalamus, but not in the other parts of the central nervous system. It was therefore concluded that the site of production of TRF is the anterior hypothalamus.

\section{REFERENCES}

Bogdanove, E. M. and N. S. Halmi (1953). Endocrinology 53, 247.

Cahane, M. and T. Cahane (1938). Acta Med. Scand. 94, 320.

Crooke, A. C. and J. D. Mathews (1953). Ciba Foundation Colloquia on Endocrinology 5, 25.

Greer, M. A. (1952). J. Clin. Endocrinol. and Metabolism 12, 1259.

Harris, G. W. (1948). Physiol. Revs. 28, 139. 
Harris, G. W. (1950). J. Physiol. 111, 247.

Nishi, K. (1959). Folia Endocrinologica Japonica 34, 1025. (In Japanese)

Shibusawa, K., S. Saito, K. Nishi, T. Yamamoto, C. Abe and K. Tomizawa (1956a). Endocrinol. Japon. 3, 116.

Shibusawa, K., K. Nishi and C. Abe (1959a). Endorrinol. Japon. 6, 31.

Shibusawa, K., T. Yamamoto, K. Nishi, C. Abe and S. Tomie (1959b). Endocrinol. Japan. 6, 131.

Shibusawa, K., T. Yamamoto, K. Nishi, C. Abe and S. Tomie (1959c). Endocrinol. Japon. 6, 137. 